DOI: http://dx.doi.org/10.25181/jofsa.v2i1.1051

Journal of Food System and Agribusiness Vol. 2 (1): 1-7

\title{
ANALISIS USAHATANI DAN PEMASARAN KEDELAI VARIETAS ANJASMORO DI KABUPATEN LAMPUNG TIMUR
}

\author{
ANALYSIS OF FARMING AND MARKETING OF ANJASMORO VARIETY SOYBEAN \\ IN LAMPUNG TIMUR REGENCY
}

\author{
Dayang Berliana ${ }^{1)}$, \\ ${ }^{1}$ Staf Pengajar PS Agribisnis Politeknik Negeri Lampung \\ e-mail: *11 dayang@polinela.ac.id
}

\begin{abstract}
Soybean is the main source of vegetable protein and vegetable oil consumed widely by the people of Indonesia. Soybean as one of the legumes plants becomes the basic ingredients of many foods such as ketchup, tofu, and tempeh. The high consumption of soybean products makes the Indonesian people highly dependent on soybeans. Therefore, it is essential to carry out a research about farming analysis and marketing channel of local soybeans which has been cultivated by farmers in North Raman District. This is because the marketing of soybean crops will determine the income that will be obtained by farmers later. This study aims to determine the income, financial feasibility, and marketing channels of soybeans in North Raman District East Lampung regency. The information of the study is important as it provides a clear description of local soybean marketing in Lampung that can be useful for soybean self-sufficiency program. This study used primary and secondary data. Primary data is data obtained collected directly from the field by sampling while secondary data is data obtained from provincial and central BPS (statistic agency) offices, and related institutions. Data analysis is done by tabulating the data, calculating the income and financial feasibility, and describing marketing channel of Anjasmoro soybean variety. Cultivation of Anjasmoro soybean in North Raman Subdistrict, both through breeding or not breeding, turns out to be profitable and financially feasible to undertake. There are 3 marketing channels that are commonly used by the respondent farmers. They are channel 1, 2, and 3. Channel 1 is the channel with the flow from farmers to village-level collectors who have contracts, licensed distributors or farmers to village-level collectors who have contracts, tofu / tempeh producers; Channel 2 is the one with the flow from the farmers directly selling to the producer of tofu / tempeh; and channel 3 is the one with the flow from farmers to village collecting trader, then to retailer, then to producers of tofu / tempeh.
\end{abstract}

Keywords: Anjasmoro Soybean, Income, Marketing Channels

Disubmit :30 April 2018 Diterima:30 Maret $2018 \quad$,Disetujui :1 April 2018

\section{PENDAHULUAN}

Kedelai merupakan sumber utama protein nabati dan minyak nabati yang banyak dikonsumsi oleh penduduk Indonesia. Kedelai dijadikan sebagai salah satu tanaman polong-polongan yang menjadi bahan dasar banyak makanan seperti kecap, tahu, dan tempe. Tingginya konsumsi produk hasil olahan kedelai menjadikan masyarakat Indonesia sangat tergantung dengan kedelai. Menurut Iswara (2010) konsumsi kedelai di Indonesia mencapai 2,2 juta tons per tahun, dari jumlah itu sekitar 1,6 juta ton harus 
diimpor. Impor komoditas kedelai yang sangat tinggi tersebut membuat pemerintah terus mengeluarkan kebijakan untuk dapat berswasembada kedelai. Salah satu upaya yang dilakukan pada Tahun 2015 yakni upaya khusus peningkatan produksi padi, jagung dan kedelai melalui program perbaikan jaringan irigasi dan sarana Pendukungnya.

Kabupaten di Provinsi Lampung yang menjadi sentra tanaman kedelai adalah Kabupaten Lampung Timur. Menurut Dinas Pertanian Kabupaten Lampung Timur (2015) Lampung Timur memiliki prospek yang baik dalam pengembangan kedelai, karena memiliki potensi lahan pertanian yang cukup luas, yakni mencapai 247.580 hektar. Salah satu Kecamatan di Kabupaten Lampung Timur yang memiliki luas panen kedelai terluas selama tiga tahun terakhir adalah kecamatan Raman Utara.

Varietas kedelai yang dibudidayakan di Kecamatan Raman Utara adalah varietas Anjasmoro. Kedelai varietas Anjasmoro ini dilepas 22 Oktober tahun 2001 dengan SK Mentan : 537/Kpts/TP.240/10/2001. Varietas unggulan ini disenangi petani karena produksinya tinggi, bijinya besar, dan polong tidak mudah pecah (Jumakir dan Endrizal 2003). Varietas Anjasmoro memiliki daya hasil 2,03-2,25 t/ha, tahan rebah, dan moderat terhadap penyakit karat daun (Balitkabi, 2008)

Produktivitas rata-rata kedelai tertinggi di Kecamatan raman Utara tercapai pada tahun 2014 yaitu sebesar13,87 kuintal/ha dengan luas panen 150 ha (BP3K Raman Utara, 2015). Desa di Kecamatan Raman Utara yang memiliki produktivitas kedelai tinggi adalah Desa Rejo Binangun. Produktivitas yang dapat dicapai yakni 15,68 kuintal/ha, hal ini menunjukkan bahwa Desa Rejo Binangun memiliki potensi untuk pengembangan kedelai dibandingkan target produktivitas kedelai nasional sebesar 14 kuintal/ha.

Tingginya produktivitas kedelai lokal di Kecamatan Raman Utara hendaknya disertai dengan efisiensi pemasaran hasil panen kedelai. Pemasaran boleh dikatakan merupakan ujung tombak dari suatu usaha produksi atau merupakan faktor yang memegang peranan penting dalam meningkatkan pendapatan petani. Usaha peningkatan produksi yang tidak disertai sistem

pemasaran yang baik akan menyebabkan sulitnya laju produk saat panen

dan hal ini akan menurunkan minat petani untuk berproduksi.

Permasalahan yang dihadapi oleh petani kedelai di Kecamatan Raman Utara yaitu tataniaga kedelai belum kondusif, jaminan pasar dan pemasaran bagi produsen kedelai lokal masih sangat lemah, namun disisi lain kedelai impor lebih mudah dan lebih murah dengan mutu yang lebih baik untuk didapatkan sebagai bahan baku industri lokal pengolahan hasil kedelai, sehingga petani yang rata-rata petani kecil kurang dapat bersaing dalam memasarkan hasil budidaya kedelainya, petani sangat tergantung pada tengkulak/ pedagang pengumpul kedelai sehingga harga yang didapatkan tidak sesuai dengan modal yang telah dikeluarkan dan pada akhirnya petani akan enggan kembali menanam kedelai. Oleh karena itu diperlukan suatu penelitian tentang analisis usahatani dan saluran pemasaran kedelai lokal yang telah diusahakan oleh petani di Kecamatan Raman Utara. Hal ini karena pemasaran hasil panen kedelai sangat menentukan pendapatan yang akan diperoleh petani nantinya.

Penelitian ini bertujuan untuk mengetahui pendapatan, kelayakan finansial serta saluran pemasaran kedelai di Kecamatan Raman Utara Kabupaten Lampung Timur. Informasi tersebut penting sebagai gambaran pemasaran kedelai lokal di Lampung yang dapat menjadi pertimbangan menuju swasembada kedelai. .

\section{METODE}

Penelitian ini merupakan penelitian yang didanai oleh DIPA Politeknik Negeri Lampung. Metode penelitian menggunakan metode deskriptif dan analitis. Data yang digunakan adalah data primer dan data sekunder. Data primer yaitu data yang diperoleh langsung di lapangan dengan melakukan sampling sedangkan data sekunder merupakan data yang diperoleh dari kantor BPS propinsi dan pusat, serta institusi terkait. Analisis 
data dilakukan dengan mentabulasi data kemudian menghitung pendapatan, kelayakan finansial dan mendeskripsikan saluran pemasaran kedelai varietas anjasmoro tersebut.

\section{HASIL DAN PEMBAHASAN}

\section{Analisis Pendapatan dan Efisiensi / Kelayakan Usahatani Kedelai}

Data hasil penelitian usahatani petani penangkar kedelai varietas Anjasmoro yang telah ditabulasi dan dihitung dapat dilihat pada Tabel 1.

Tabel 1. Rata-rata Hasil Perhitungan Analisis Pendapatan dan Kelayakan Usahatani Petani Penangkar Kedelai Varietas Anjasmoro per Hektar di Kecamatan Raman Utara Lampung Timur

\begin{tabular}{|c|c|c|c|c|}
\hline \multirow[b]{2}{*}{ Uraian } & \multicolumn{2}{|c|}{$\begin{array}{l}\text { Per luas lahan rata-rata usahatani } \\
0,95 \text { ha }\end{array}$} & \multicolumn{2}{|c|}{ Per Ha Lahan usahatani } \\
\hline & $\begin{array}{c}0,95 \text { ha } \\
\text { Nilai/Hasil Perhitungan }\end{array}$ & Ket & Nilai/Hasil Perhitungan & Ket \\
\hline $\begin{array}{l}\text { Jumlah produksi kedelai } \\
(\mathrm{Kg})\end{array}$ & $2.355,50$ & & $2.473,275$ & \\
\hline Harga Jual Kedelai & & & & \\
\hline$(\mathrm{Rp} / \mathrm{Kg})$ & $10.000,00$ & & $10.000,00$ & \\
\hline Total Penerimaan (Rp) & $23.555 .000,00$ & & 24.732 .750 & \\
\hline Total Biaya Produksi (Rp) & $12.923 .307,00$ & & $13.569 .472,35$ & \\
\hline Pendapatan bersih (Rp) & $10.631 .693,00$ & & $11.163 .277,65$ & \\
\hline RC Ratio & 1,82 & Layak & 1,82 & Layak \\
\hline $\mathrm{BEP}(\mathrm{Q})$ produksi $(\mathrm{Kg})$ & $1.292,33$ & & $1.356,95$ & \\
\hline Produksi riil $(\mathrm{Kg})$ & $2.355,50$ & Layak & $2.473,275$ & Layak \\
\hline $\mathrm{BEP}(\mathrm{Rp})$ harga & $5.486,44$ & & $5.486,44$ & \\
\hline Harga Riil (Rp) & $10.000,00$ & Layak & $10.000,00$ & Layak \\
\hline ROI (\%) & 82,27 & Untung & 82,27 & Untung \\
\hline
\end{tabular}

Sumber: Data primer diolah, 2016

Pendapatan petani penangkar kedelai varietas anjasmoro adalah penerimaan dikurang dengan biaya produksi perluas garapan petani. Biaya produksi yang dikeluarkan oleh petani responden untuk setiap musim tanam terdiri dari biaya tunai dan biaya diperhitungkan. Biaya tunai berasal dari pembayaran iuran irigasi, dan pajak lahan, sedangkan biaya diperhitungkan berasal dari biaya tenaga kerja dalam keluarga dan penyusutan alat, sewa lahan dan biaya variabel yang merupakan bantuan sosial dari Departemen Sosial.

Penerimaan petani responden usahatani kedelai adalah perkalian antara harga jual dan jumlah produksi. Produksi kedelai varietas Anjasmoro hasil penangkaran per luas 0,955 hektar sebesar 2355,50 $\mathrm{kg}$ atau sebesar $2473,275 \mathrm{~kg} / \mathrm{ha}$. Harga rata-rata kedelai varietas anjasmoro hasil penangkaran ialah Rp 10.000 sedangkan harga rata-rata kedelai bukan hasil penangkaran di daerah penelitian yaitu Rp. 8.110/kg.

Tabel 1 dan 2 menunjukkan pendapatan petani penangkar kedelai Anjasmoro per 0,95 ha atas atas biaya total sebesar Rp10631693,00 . Sedangkan pendapatan usahatani kedelai Anjasmoro bukan hasil penangkaran per 0.375 ha atas biaya total sebesar Rp1471734,38. Nisbah penerimaan terhadap biaya total pada usaha penangkaran kedelai lokal sebesar 1,82 artinya setiap Rp. 1,00 biaya total yang dikeluarkan akan menghasilkan penerimaan sebesar Rp. 1,82. Nisbah penerimaan atas biaya total bernilai lebih besar dari 1,00 artinya usaha penangkaran kedelai varietas Anjasmoro yang dilakukan oleh petani responden secara ekonomi menguntungkan. Nisbah penerimaan terhadap biaya total pada usahatani kedelai lokal bukan hasil penangkaran lebih rendah dibandingkan hasil penangkaran yaitu 1,36 artinya setiap Rp. 1,00 biaya total yang dikeluarkan akan menghasilkan penerimaan sebesar Rp. 1,36. Nisbah penerimaan atas biaya total bernilai lebih besar dari 1,00 artinya usaha penangkaran kedelai varietas Anjasmoro yang dilakukan oleh petani responden 
secara ekonomi menguntungkan. Rendahnya $\mathrm{R} / \mathrm{C}$ ratio kedelai bukan hasil penangkaran karena harga jual kedelai berbeda dengan harga jual kedelai hasil penangkaran. Kedelai hasil penangkaran dijual dengan harga yang lebih tinggi karena mendapat proses teknologi pasca panen yang lebih baik yaitu melakukan proses grading.

Tabel 2. Rata-rata Hasil Perhitungan Analisis Pendapatan dan Kelayakan Usahatani Petani Kedelai Varietas Anjasmoro per Hektar di Kecamatan Raman Utara Lampung Timur

\begin{tabular}{|c|c|c|c|c|}
\hline \multirow[b]{2}{*}{ Uraian } & \multicolumn{2}{|c|}{$\begin{array}{l}\text { Per luas lahan rata-rata usahatani } \\
\qquad 0,3875 \text { ha }\end{array}$} & \multicolumn{2}{|c|}{ Per Ha Lahan usahatani } \\
\hline & Nilai/Hasil Perhitungan & Ket & Nilai/Hasil Perhitungan & Ket \\
\hline $\begin{array}{l}\text { Jumlah produksi kedelai } \\
(\mathrm{Kg})\end{array}$ & 681,25 & & $1.757,625$ & \\
\hline Harga Jual Kedelai (Rp/Kg) & $8.110,00$ & & $8.110,00$ & \\
\hline Total Penerimaan (Rp) & $5.524 .937,50$ & & $14.254 .338,75$ & \\
\hline Total Biaya Produksi (Rp) & 4.053.203,13 & & $10.457 .264,06$ & \\
\hline Pendapatan bersih (Rp) & $1.471 .734,38$ & & $3.797 .074,688$ & \\
\hline RC Ratio & 1,36 & Layak & 1,36 & Layak \\
\hline BEP (Q) produksi (Kg) & 499,78 & & $1.289,43$ & \\
\hline Produksi riil $(\mathrm{Kg})$ & 681,25 & Layak & $1.757,625$ & Layak \\
\hline BEP (Rp) harga & $5.949,66$ & & $5.949,66$ & \\
\hline Harga Riil (Rp) & $8.110,00$ & Layak & $8.110,00$ & Layak \\
\hline ROI (\%) & 36,31 & Untung & 36,31 & Untung \\
\hline
\end{tabular}

Sumber: Data primer diolah, 2016

Dari sisi analisis produksi menunjukkan bahwa tingkat produksi kedelai Varietas Anjasmoro baik hasil penangkaran maupun bukan hasil penangkaran di daerah penelitian sudah mencapai di atas titik impas (BEP-produksi). Produksi rata-rata riil sebesar 2.586 $\mathrm{kg} / \mathrm{ha}$ sedangkan BEP produksi hanya sebesar $2.473,275 \mathrm{~kg} / \mathrm{ha}$ dan $1.757,625 \mathrm{~kg} / \mathrm{ha}$. Hasil analisis BEP harga menunjukkan bahwa harga riil yaitu Rp. 10.000,-/kg dan 8.110 $\mathrm{Kg}$ yang diperoleh jauh lebih besar dibanding harga BEP yang hanya sebesar Rp. $5.486,44,-/ \mathrm{kg}$ dan $5.949,66,-/ \mathrm{kg}$. Demikian juga pada hasil analisis ROI penelitian menunjukkan hasil angka $82,27 \%$, tetapi untuk usahatani bukan penangkaran ROI hanya $36,31 \%$. Semua ini dapat disimpulkan bahwa usahatani kedelai varietas Anjasmoro penangkaran di daerah penelitian menunjukkan lebih layak secara finansial dan menguntungkan dibandingkan dengan usahatani bukan hasil penangkaran. Dengan meningkatkan kualitas produksi, pemasaran produk (tiwul instan) dapat dimanfaatkan oleh masyarakat dengan baik tetapi juga harus memiliki inovasi baru untuk menjaga pemintaan sehingga meningkatkan penjualan dan pendapatan usaha (tiwul instan) akan lebih meningkat. (Zulkarnain, 2017)

\section{Analisis Pemasaran Kedelai Varietas Anjasmoro}

Saluran Pemasaran Kedelai

Pemasaran kedelai lokal merupakan proses pertukaran yang mencakup serangkaian kegiatan untuk menyampaikan komoditas kedelai lokal dari petani produsen kepada konsumen akhir di pasar Kota Metro. Berdasarkan hasil penelitian, pemasaran kedelai lokal dapat digambarkan sebagai berikut. 


\section{Saluran Pemasaran I}

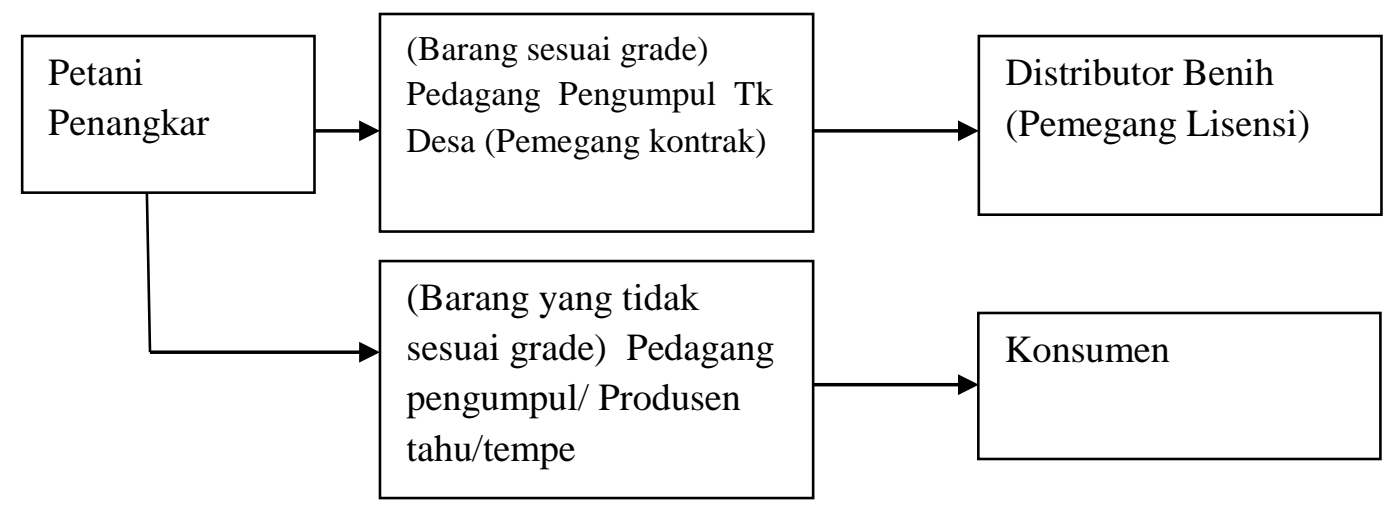

Gambar 1. Saluran pemasaran I kedelai lokal Kecamatan Raman Utara Kabupaten Lampung Timur, tahun 2016

Pada Gambar 1 dapat dilihat bahwa saluran kedelai lokal di Kecamatan Raman Utara, yaitu :

Saluran I : Petani $\rightarrow$ Pedagang pengumpul tingkat desa yang memegang kontrak $\rightarrow$ Distribusi benih

Pada saluran pemasaran II, terdapat petani kedelai lokal yang menjadi petani penangkar, kedelai hasil tangkarannya yang sesuai grade dijual kepada pedagang pengumpul yang telah melakukan kontrak dengan petani penangkar. Selanjutnya pedagang pengumpul nantinya akan menjual benih kedelai tersebut ke perusahaan benih. Kedelai lokal yang tidak sesuai grade akan dijual petani ke produsen tahu/tempe yang nantinya olahan kedelai tersebut langsung dijual kepada konsumen.

\section{Saluran Pemasaran II}

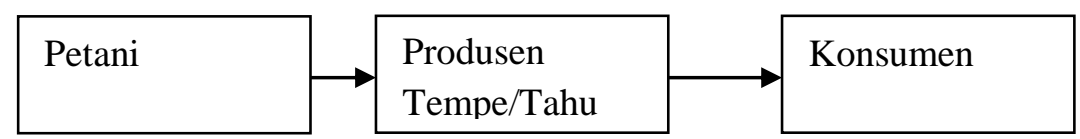

Gambar 2. Saluran pemasaran II kedelai lokal Kecamatan Raman Utara Kabupaten Lampung Timur, tahun 2016

Pada Gambar 2 dapat dilihat bahwa saluran kedelai lokal di Kecamatan Raman Utara, yaitu :

Saluran II : Petani $\rightarrow$ Produsen tahu/tempe $\rightarrow$ konsumen

Pada saluran pemasaran III, petani kedelai lokal menjual kedelainya kepada produsen tahu/tempe/kecambah. Produsen tahu/tempe/kecambah nantinya langsung menjual tahu/tempenya kepada konsumen. Kecambah umumnya dikonsumsi masyarakat sebagai tambahan sayuran.

\section{Saluran Pemasaran III}

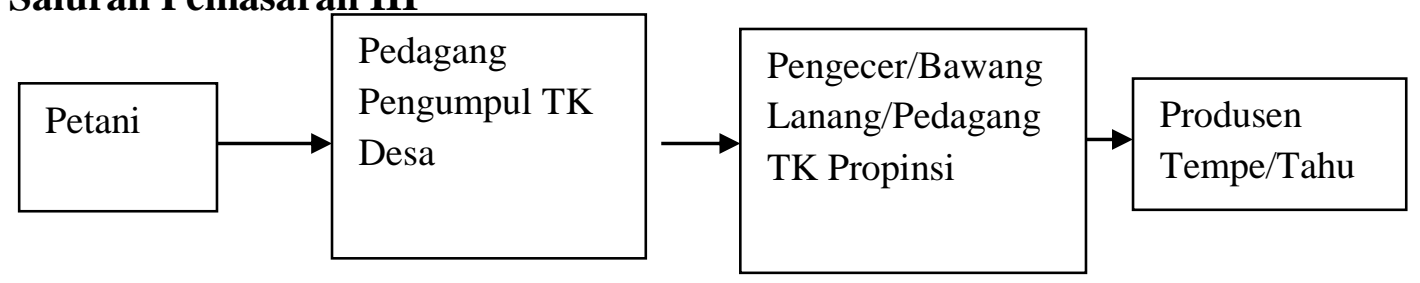

Gambar 3. Saluran pemasaran III kedelai lokal Kecamatan Raman Utara Kabupaten Lampung Timur, tahun 2016 
Saluran III : Petani $\rightarrow$ Pedagang pengumpul TK Desa $\rightarrow$ Pengecer/Bawang lanang $\rightarrow$ Produsen Tempe/Tahu

Pada saluran pemasaran III, petani kedelai lokal menjual kedelainya kepada pedagang pengumpul tingkat desa, pedagang pengumpul tingkat desa selanjutnya menjual kepada pengecer atau biasa disebut bawang lanang, kemudian pengecer langsung menjual ke konsumen.

\section{Struktur dan Perilaku Pasar Kedelai}

Struktur dan perilaku pasar yang dihadapi petani kedelai di Kecamatan Raman Utara ialah jumlah pembeli di level petani lebih sedikit dibandingkan dengan jumlah penjualnya (petani). Hal inilah yang menyebabkan posisi tawar petani rendah. Sifat produk kedelai relatif homogen. Berkaitan dengan informasi harga, petani umumnya memperoleh informasi harga dari sesama petani dan lembaga pemasaran di atasnya, sedangkan pedagang desa memperoleh informasi harga dari produsen tahu/tempe. Dalam penentuan harga petani tidak dilibatkan sehingga petani sebagai menerima harga (price taker). Hambatan untuk keluar masuk pasar di tingkat petani relatif lebih mudah dibandingkan menjadi pedagang tingkat desa khususnya pedagang yang membeli benih kedelai hasil penangkaran karena pedagang tersebut harus memiliki kontrak dengan petani. Hambatan distributor benih kedelai lokal paling sulit karena distributor harus memiliki lisensi untuk dapat membeli benih kedelai dan memasarkannya.

Penjualan dan pembelian kedelai dilakukan dilokasi petani, walaupun beberapa petani melakukan transaksi di lokasi pedagang desa. Pada saat transaksi biasanya kedelai hasil panen petani dilakukan pengecekan setelah dicek pedagang akan menentukan harga kedelai tersebut. Sistem pembayaran yang dilakukan pedangang ke petani adanya yang sistem tunai tetapi ada pula yang menggunakan jangka waktu. Harga yang dinikmati petani juga belum memberikan kepuasan kepada petani. Petani masih menghadapi masalah kurang diminatinya kedelai lokal dibandingkan kedelai impor.

\section{SIMPULAN}

1. Usahatani kedelai varietas Anjasmoro di Kecamatan Raman Utara baik hasil penangkaran maupun bukan hasil penangkaran dari segi pendapatan menguntungkan dan layak secara finansial untuk diusahakan.

2. Saluran pemasaran yang banyak dilalui oleh petani responden terdapat 3 saluran yang terbentuk antara lain saluran 1, yaitu saluran dengan alur dari petani ke pedagang pengumpul tingkat desa yang memiliki kontrak, distributor berlisensi atau petani ke pedagang pengumpul tingkat desa yang memiliki kontrak, produsen tahu/tempe, saluran ke II yaitu dari petani langsung jual ke produsen tahu/tempe dan saluran III yaitu saluran dengan alur dari petani ke pedagang pengumpul tingkat desa ,lalu ke pedagang pengecer/bawang lanang lalu ke produsen tahu/tempe.

\section{DAFTAR PUSTAKA}

Amstrong, G., \& Philip, K. (2000). Dasar-dasar Pemasaran. Jilid 1, Alih. Bahasa Alexander Sindoro dan Benjamin Molan.

Assauri, S. (1987). Manajemen pemasaran: dasar, konsep den strategi. CV Rajawali. 
Berliana, Dayang. (2013). Analisis Sistem Pemasaran dan Strategi Pengembangan Usahatani Manggis (Studi Kasus di Kabupaten Tanggamus). Tesis Magister Agribisnis Universitas Lampung. Bandar Lampung.

BP3K Raman Utara. (2015). Laporan Pelaksanaan Gerakan Penerapan Pengelolaan Tanaman Terpadu (GP-PTT) Kedelai dan Perluasan Areal Tanam (PAT) Kedelai Kecamatan Raman Utara Tahun 2015. Pemerintah Kabupaten Lampung Timur. Sukadana.

Dinas Pertanian Kabupaten Lampung Timur. 2015. Angka Perhitungan Produksi Tanaman Pangan dan Hortikultura Kabupaten Lampung Timur Tahun 2015. Pemerintah Kabupaten Lampung Timur. Sukadana.

Hanafie, R. (2010). Pengantar ekonomi pertanian. Penerbit Andi.

Iswara.(2010). Kedelai Setelah Satu Dekade. Majalah Tempo. Diakses dari http://majalah. tempointeraktif. com/id/arsip/2010/03/29/EB/mbm\} . Diunduh 6 Juni 2017.

Limbong, S. (1987). Pengantar Tataniaga Pertanian (Bahan Kuliah Jurusan Ilmu-ilmu Sosial Ekonomi Pertanian). Institut Pertanian Bogor. Bogor.

Maryani, Nora. (2008). Analisis Usaha dan Tataniaga Kedelai di Kecamatan Ciranjang, Kabupaten Ciganjur, Jawa Barat. Skripsi. Manajemen Agribisnis. Fakultas Pertanian. Institut Pertanian Bogor.Bogor.

Ramlah. (2014). Analisis Saluran dan Marjin Pemasaran Kedelai di Desa Ugi, Kecamatan Sabbangparu, Kabupaten Wajo, Sulawesi Selatan.Skripsi Agribisnis. Fakultas Pertanian. Universitas Hasanudin. Makasar.

Winandi, R., Tinaprilla, N., \& Rifin, A. Sistem Pemasaran Kedelai Di Kabupaten Lamongan Provinsi Jawa Timur.

Zulkarnain, Z. (2017). Analisis Strategi Pengembangan Pemasaran dan Nilai Tambah Tiwul Instan. Journal of Food System and Agribusiness (JoFSA), 1(1), 1-11. Retrieved from http://jurnal.polinelasrv.id/index.php/JOFSA/article/view/79 